\title{
Physical, physiological, and sanitary quality of Myrocarpus frondosus Allemão diaspores stored in different environments
}

\author{
Suelen Carpenedo Aimi ${ }^{1}$ \\ Maristela Machado Araujo ${ }^{1}$ (]) \\ Marlove Fatima Brião Muniz ${ }^{2}$ (1) \\ Clair Walker ${ }^{2}$ (]) \\ Daniele Rodrigues Gomes ${ }^{1}$
}

\begin{abstract}
Cabreúva (Myrocarpus frondosus Allemão) is a native species with ecological, ornamental, medicinal, and timber potential. This study aimed to evaluate the physical, physiological, and sanitary quality of Myrocarpus frondosus diaspores over 360 days in different storage environments. The initial characterization of the batch included the weight of 1,000 seeds, moisture content, electrical conductivity, germination potential (with substrates being between and on sand or vermiculite, and a paper roll) and sanitary quality (blotter test). The diaspores were stored in a room with ambient conditions, a dry and cold room, a wet and cold chamber, and a refrigerator. Evaluations were performed at $0,90,180,270$, and 360 days. The substrates between sand and between vermiculite are recommended for the germination of diaspores. Diaspores showed no recalcitrant behavior in relation to storage and can be stored in a dry and cold room $\left(18{ }^{\circ} \mathrm{C}\right.$ and $\left.49 \% \mathrm{RH}\right)$ for 360 days, with $57 \%$ germination. Fungal incidence increased the deterioration of the diaspores after 180 days of storage in a cold and dry environment.
\end{abstract}

Keywords: Fabaceae, cabreúva, native species, germination, sanity.

\section{INTRODUCTION}

Most projects for the conservation, exploration, and restoration of tree species depend on the production of quality seedlings (Kissmann et al., 2009). The direct sowing of seeds of native tree species can be a low-cost alternative to forest restoration (Huller et al., 2017). Thus, considering that seeds represent a critical stage in the survival of higher plants (Nguyen et al., 2015) and that most native species are still propagated via sexual reproduction, research is essential on the physical, sanitary, and physiological qualities of seeds. There is still a gap in the quality control of seeds of several tree species, owing to the lack of standards established for their analysis (Ribeiro-Oliveira \& Ranal, 2014), regarding information on the occurrence of potentially pathogenic fungi to seeds internally and/or externally.
The cabreúva belongs to the Fabaceae family, and occurs in Bolivia, Argentina, Paraguay, and Brazil, mainly in the Deciduous and Semideciduous Seasonal Forest (Carvalho, 2003). It stands out among the native species of greater commercial wood production, and is used in the perfumery and dye industry, urban afforestation, reconstitution of altered ecosystems, and replacement of riparian forest, in addition to having medicinal properties (Carvalho, 2003; Santi et al., 2017).

Normally, in a seedling nursery the seeds are not used immediately after collection, but are stored for future use. Therefore, it is necessary to maintain their viability during storage and reduce the speed of the deterioration process through technologies appropriate to each species (Kissmann et al., 2009). Thus, it is very important to check efficient methods and storage conditions to maintain their viability

${ }^{1}$ Universidade Federal de Santa Maria (UFSM), Centro de Ciências Rurais, Departamento de Ciências Florestais, Santa Maria, RS, Brasil ${ }^{2}$ Universidade Federal de Santa Maria (UFSM), Departamento de Defesa Fitossanitária, Santa Maria, RS, Brasil 
(Araujo et al., 2017). Some research with seeds of forestry species has been conducted to verify this characteristic in different packaging and storage environments, determining techniques to increase the conservation period (Gasparin et al., 2013; Tonetto et al., 2015; Vicente et al., 2016).

The physical quality of a seed lot or sample refers to morphological aspects, such as mass, specific mass, mechanical injuries and/or morphotypical purity. Physical quality is associated with visible changes in seed structure or appearance. Physical characteristics are obtained as the result of the purity tests, moisture content, weight of one thousand seeds, and number of seeds per kilogram (Brasil, 2009a). The physiological quality of seeds can be determined through germination tests. Sanitary quality is related to the presence or absence of pathogens, such as fungi, bacteria, viruses, nematodes, and insects in the seeds (Brasil, 2009b), and is evaluated using the sanitary test (blotter test).

The deterioration process occurs because of physical, physiological, and biochemical reactions that occur in seeds, leading to loss of viability. The speed of the deterioration process in seeds of some native species is very high and the period in which the viability can be maintained varies from a few weeks to a few months, as is the case with Myrocarpus frondosus Allemão (cabreúva) diaspores. These are samaratype indehiscent fruits with winged expansions and have controversial classification in the literature, being described as recalcitrant (Lorenzi, 2002) and intermediate (Wielewicki et al., 2006) to storage with low viability in an uncontrolled environment, ranging from three to six months.

Therefore, the objective of this study was to evaluate the physical, physiological, and sanitary of the diaspores of Myrocarpus frondosus over 360 days in different storage environments.

\section{MATERIAL AND METHODS}

Diaspores of Myrocarpus frondosus Allemão were collected in December 2014 from 12 trees located in forest fragments in the municipality of Nova Palma, RS ( $9^{\circ} 28^{\prime} 25,09^{\prime \prime} S$ and $\left.53^{\circ} 17^{\prime} 50,8^{\prime \prime} \mathrm{O}\right), 100 \mathrm{~m}$ apart. For this season, according to the Meteorological Department of the Phytotechnics Department of the Federal University of Santa Maria, in the year 2014 , the average temperature was $21.2^{\circ} \mathrm{C}$, the average maximum and minimum temperature was $26.0^{\circ} \mathrm{C}$ and $16.0^{\circ} \mathrm{C}$, respectively, and average precipitation was $187.4 \mathrm{~mm}$. After collection, all diaspores were homogenized manually (forming a single batch) and placed in trays on tables in a covered and ventilated environment, kept for two days with daily turning, and subsequently placed in a paper bag.
The use of cabreúva diaspores in the present study is because of the difficulty in removing seeds from them without compromising and/or damaging the embryo structure. Only the winged structures were removed, with the aid of scissors to facilitate handling during tests.

\subsection{Initial physical and physiological quality assessment}

The batch characterization was conducted by evaluating the weight of 1,000 seeds (eight repetitions of 100 seeds) of the diaspores with and without wings and the degree of moisture content of the diaspores without wings by the greenhouse method, at $105^{\circ} \mathrm{C}$ for $24 \mathrm{~h}$ (Brasil, 2009a). Additionally, the electrical conductivity (EC) was determined by the mass method, using four repetitions of 25 diaspores without wings, previously weighed on a precision electronic scale $(0.001 \mathrm{~g})$ and packed in plastic cups with $100 \mathrm{~mL}$ of distilled water. The cups were wrapped with aluminum foil and kept in a germination chamber at a constant temperature of $25^{\circ} \mathrm{C}$ for $24 \mathrm{~h}$. After soaking, the solution was homogenized, and the leachate used in a conductivity meter.

\subsection{Germination test}

First, an experiment was performed in order to identify the best substrate for conducting the germination test. In this test, transparent boxes of the type "Gerbox," were used with four repetitions of 25 diaspores without wings, in a completely randomized design. The treatments (substrates) were: T1 - Between sand (BS) (fine and sieved in a $0.84 \mathrm{~mm}$ mesh, with $200 \mathrm{~g}$ at the bottom of the "gerbox" and $100 \mathrm{~g}$ on top of the diaspores, moistened with $45 \mathrm{~mL}$ of distilled water); T2 - On sand (OS) (fine and sieved in a $0.84 \mathrm{~mm}$, with $300 \mathrm{~g}$, moistened with $45 \mathrm{~mL}$ of distilled water); T3 Between vermiculite (BV) (17 g at the bottom and $10 \mathrm{~g}$ at the top, moistened with $83 \mathrm{~mL}$ of distilled water); $44-\mathrm{On}$ vermiculite (OV) (27 g at the bottom, moistened with $83 \mathrm{~mL}$ of distilled water); and T5 - roller paper (RP) (three sheets moistened to 2.5 times the weight of the paper, placed inside bags plastics). To calculate the amount of water to be added to the substrates, the method proposed by Brazil (2009a, 2013) was followed.

The substrates were sterilized in an autoclave at $120^{\circ} \mathrm{C}$ for $1 \mathrm{~h}$, and the "gerbox" sterilized with 70\% alcohol and then with $1 \%$ sodium hypochlorite. Disinfection of diaspores was performed according to Brazil (2013) with five drops of neutral detergent in $100 \mathrm{~mL}$ of water for $10 \mathrm{~min}$, after washing thrice in distilled water. The gerboxes were placed in a Mangelsdorf ${ }^{\oplus}$ germination chamber with a temperature 
of $25 \pm 2{ }^{\circ} \mathrm{C}$ and $8 / 16 \mathrm{~h}$ photoperiod (light/dark). The counts of germinated diaspores (normal seedlings, Figure $1 \mathrm{G}$ ) were performed every three days; germination started on the 9th day after installation of the test, the first count was performed on the 15th day, and the last count on the 27th day, considering the physical criterion in which all essential structures are visible (Brazil, 2009a). From these data it was possible to calculate the germination percentage (G\%), abnormal seedlings, and the germination speed index (GSI) (Maguire, 1962). As per the physical criterion, a seedling is considered normal when presenting well-developed essential structures (aerial and root) that are complete, proportional, and sanitary (Brasil, 2009a). At the end of the germination test, firm (hard) diaspores were evaluated and killed as described in Brasil (2013).

\subsection{Sanitary quality}

The sanitary test was performed in January 2015. The diaspores were distributed in "gerbox," disinfected with 70\% alcohol and $1 \%$ sodium hypochlorite, and lined with two sterile filter paper sheets moistened with distilled and sterilized water, with four repetitions of 25 seeds each (Brasil, 2009b). Incubation was performed in a chamber with temperature controlled at $25^{\circ} \mathrm{C}$ and a photoperiod of $12 \mathrm{~h}$ of fluorescent light for 7 days. After this period, the quantification and identification of fungi in each diaspore was performed at the genus level based on their morphological characteristics with the aid of stereoscopic and optical microscopes and specialized bibliography (Barnett \& Hunter, 1999).

\subsection{Physiological and sanitary quality during storage}

Storage of diaspores in different environments was begun in January 2015 and continued until January 2016. Diaspores were stored in Kraft paper bags. The design was completely randomized in a $4 \times 5$ factorial design, with plots subdivided over time (environments $\times$ storage time) with four repetitions of 25 diaspores for each environment. The environments (treatments) were: RAC - room at ambient conditions (average temperature $21.4^{\circ} \mathrm{C} \pm 3^{\circ} \mathrm{C}$, maximum $26^{\circ} \mathrm{C}$, minimum $16.4^{\circ} \mathrm{C}$, and relative humidity (RH) of 79\%); DCR - dry and cold room (with air conditioning and dehumidifier, $18^{\circ} \mathrm{C} \pm 3^{\circ} \mathrm{C}$ and $49 \% \mathrm{RH})$; WCC - wet and cold chamber $\left(8^{\circ} \mathrm{C} \pm 3^{\circ} \mathrm{C}\right.$ and $86 \% \mathrm{RH})$; and REF - refrigerator $\left(3^{\circ} \mathrm{C} \pm 3^{\circ} \mathrm{C}\right.$ and $\left.48 \% \mathrm{RH}\right)$. For the room at ambient condition, temperature data (average, maximum, and minimum) and $\mathrm{RH}$ were obtained from the Meteorological Station of Santa Maria, located on the Campus UFSM. At 0 (without storage), 90, 180, 270, and 360 days of storage, were determined technological water content, EC, and germination and sanitary diaspores.

For the determination of moisture content, electrical conductivity, and sanity test in each environment, the same method as described above was followed. For the germination test, the substrate between sand was selected. The choice of this substrate was based on the initial results obtained. In the germination test, in addition to the variables described above, seedling length was measured with a graduated rule from the root to stem apex (expressed in $\mathrm{cm}$ per seedling). After this stage, the seedlings were placed in Kraft paper bags, and placed in a greenhouse with forced air circulation at a temperature of $65^{\circ} \mathrm{C}$ for $48 \mathrm{~h}$. Then, the material was weighed to obtain the dry matter weight of seedlings, and the result was divided by the number of seedlings and expressed as grams per seedling.

\subsubsection{Data analysis}

The data were analyzed for the assumptions of normality and homogeneity using the Shapiro-Wilk and Bartlett tests, respectively, through the "Action" supplement (Estatcamp Team, 2014). When the assumptions were not met, data were transformed; for germination, abnormal seedlings (when not presenting well-developed essential structures), dead diaspores and sanitary, data were transformed as arcsine $\sqrt{(x / 100)}$ and for germination speed index the transformation $\sqrt{(x+0,5)}$ was used. Data were first submitted to analysis of variance and then means compared using the Tukey test and/or polynomial regression at a $5 \%$ probability of error, with the aid of Sisvar v. 5.6 (Ferreira, 2014).

\section{RESULTS AND DISCUSSION}

\subsection{Initial physical, physiological, and sanity quality}

In the batch of Myrocarpus frondosus Allemão diaspores with wings, the weight of 1,000 seeds was $93.01 \mathrm{~g}$ (coefficient of variation $(\mathrm{CV})=3.9 \%$ ), representing 10,752 seeds $\mathrm{kg}^{-1}$, and for diaspores after removal of the wing it was $89.71 \mathrm{~g}$ $(\mathrm{CV}=3.8 \%)$, with 11,147 seeds $\mathrm{kg}^{-1}$. These results were higher than those described by Lorenzi (2002) $\left(5,100\right.$ seeds $\left.\mathrm{kg}^{-1}\right)$, but within the limits presented in Brasil (2013) of 5,000 to 17,000 seeds $\mathrm{kg}^{-1}$. The water content level was 9.2\% $(\mathrm{CV}=3.1 \%)$, close to that reported by Wielewicki et al. (2006) (9.3\%). It is evident that these results show close similarities for the characterization of the quality and marketing of seed lots. The initial EC of the batch was $11.27 \mu \mathrm{S} \mathrm{cm}^{-1} \mathrm{~g}^{-1}$, which was considered low. This variation in the weight of a thousand 
seeds and the degree of humidity may be associated with different stages of physiological maturation of diaspores and regions of collection. In the weight of the seeds there are variations within and between lots, caused by factors and environmental conditions (Schmidt, 2007).

Regarding germination, an effect for the substrates $(p<0.05)$ was observed, with higher values in the substrates BS and BV (85\% and $71 \%$, respectively) and the lowest value (43\%) in RP (Table 1). A similar result was observed for the GSI, which indicated the substrates BS and BV as the best (Table 1).

Table 1. Percentage of germination $(G)$, germination speed index (GSI), abnormal seedlings (AS), and dead diaspores (DM) of Myrocarpus frondosus Allemão on different substrates, Santa Maria, RS.

\begin{tabular}{|lcccc|}
\multicolumn{1}{c}{ Substrates } & $\begin{array}{c}\text { G } \\
(\%)\end{array}$ & GSI & $\begin{array}{c}\text { AS } \\
(\%)\end{array}$ & $\begin{array}{c}\text { DD } \\
(\%)\end{array}$ \\
\hline Between sand (BS) & $85 \mathrm{a}^{*}$ & $1.36 \mathrm{a}$ & $2 \mathrm{a}$ & $13 \mathrm{a}$ \\
\hline $\begin{array}{l}\text { On sand (OS) } \\
\text { Between vermiculite }\end{array}$ & $75 \mathrm{~b}$ & $0.87 \mathrm{~b}$ & $9 \mathrm{~b}$ & $36 \mathrm{~b}$ \\
$(\mathrm{BV})$ & $1.13 \mathrm{a}$ & $5 \mathrm{a}$ & $24 \mathrm{~b}$ \\
\hline On vermiculite (OV) & $54 \mathrm{~b}$ & $0.86 \mathrm{~b}$ & $9 \mathrm{~b}$ & $37 \mathrm{~b}$ \\
\hline Roller paper (RP) & $43 \mathrm{~b}$ & $0.62 \mathrm{~b}$ & $2 \mathrm{a}$ & $55 \mathrm{c}$ \\
\hline Mean & 62.0 & 0.97 & 5.40 & 33.6 \\
\hline CV (\%) & 15.37 & 17.54 & 44.46 & 9.99 \\
\hline
\end{tabular}

${ }^{\star}$ Means not followed by the same letter differ by the Tukey test $(p<0.05)$; CV: Coefficient of variation.

The normal seedlings of cabreúva showed complete and well-formed aerial and root parts (Figure 1). In contrast, in the abnormal seedlings, the absence of aerial parts, deformed, atrophied, and/or deteriorating root system was observed (Figure $1 \mathrm{H}$ ), and was observed mainly in the treatments in which the diaspores were on the substrates OS and OV.

In the RP substrate less germination and a higher percentage of dead diaspores was observed (Table 1). Wielewicki et al. (2006) described the use of the paper roll as a substrate for the germination test of cabreúva as indicated. However, the values observed for this substrate were lower in this study, a fact that may be associated with greater contamination by pathogens, leading to the death of the diaspores. Brasil (2013) for this species indicates the use of the substrates between sand, between vermiculite, on sand, and paper rolls. Thus, based on the results of this study, the use of the substrate between sand is recommended owing to availability, ease of handling, and lower incidence of pathogens in the germination tests for Myrocarpus frondosus. In seeds of other forest species of the same family, such as Adenanthera pavonina L. and Parkia multijuga Benth., the substrate sand was also recommended for use in the germination test (Souza et al., 2007; Rocha et al., 2014).

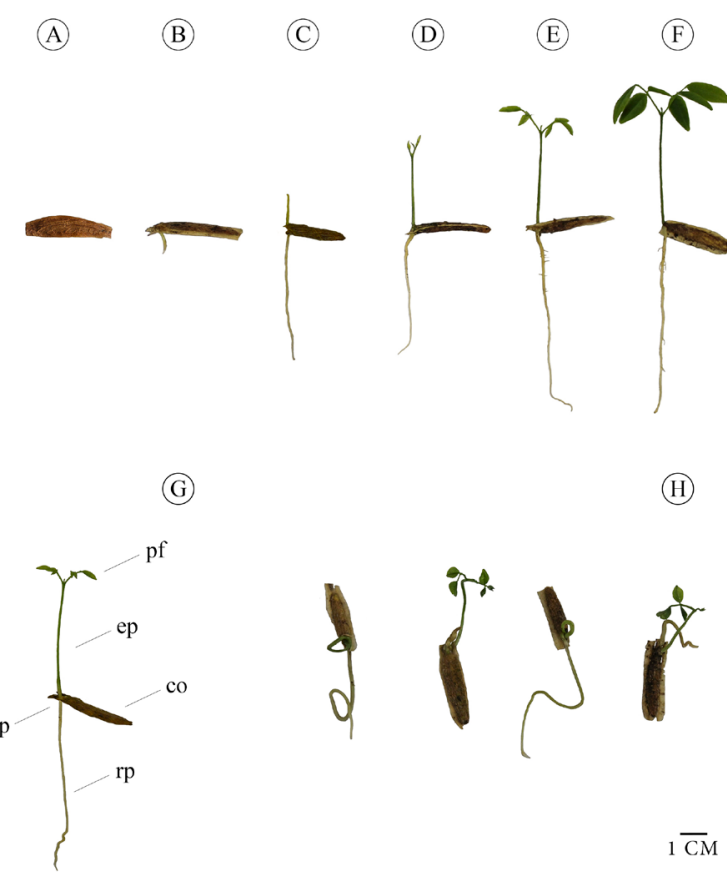

Figure 1. Successive stages of cryptocotylar hypogeal germination of Myrocarpus frondosus Allemão; winged diaspore (A); radicle emissionn (B); elongation of the primary root and cotyledon expansion (C to E); normal seedling (F); morphological aspects $(\mathrm{G})$ of seedlings, ep - epicotyl, co - cotyledons, hp - hypocotyl, rp - primary root; and abnormal seedlings $(\mathrm{H})$ observed in the germination test.

Germination of the cabreúva diaspores started on the 9th day after the test was installed; the first count was performed on the 15th day and the last count on the 27th day. Germination according to the length of the hypocotyl is hypogeal and the seedlings are classified as cryptocotyledons, i.e., the cotyledons do not emerge from the seed coat and remain inside until the end of the process (Figure 1).

In the sanitary test, the fungal genera detected were Fusarium spp. (99\%), Aspergillus spp. (13\%), Phoma spp. (12\%), Alternaria spp. (8\%), Colletotrichum spp. (4\%), Penicillium spp. (2\%), and Cladosporium spp. (2\%). Aimi et al. (2016) and Tonetto et al. (2015) also found a high incidence of Fusarium in seeds of Cabralea canjerana (Vell.) Mart. and Handroanthus heptaphyllus (Mart.) Mattos, respectively.

\subsection{Physiological and sanitary quality during storage}

After 90 days of storage, there was an increase in the degree of humidity of the diaspores in RAC and WCC 
conditions, and the loss of moisture in DCR and REF conditions. These changes occurred up to 90 days and remained with little variation until 270 days. At 360 days, there was a reduction in the diaspores moisture content in all environments (Table 2). Diaspores were stored in permeable packaging (Kraft paper bags), moisture was lost to the external environment in the DCR and REF conditions. It was observed that even with the low initial humidity $(<10 \%)$ at the time of storage, typical of orthodox seeds according to Roberts (1973), the WCC environment was inadequate, possibly owing to the packaging used in the storage.

For the germination variables, GSI, seedling length, seedling dry matter, and dead diaspores there was interaction $(p<0.05)$ between the storage conditions or environments. However, for abnormal seedlings there was no interaction $(p=0.0684)$ and no effect for environments $(p=0.1145)$ and storage ( $p=0.5136)$ (data not shown). Before being stored, the diaspores had a germination rate of $85 \%$ and 1.4 GSI. For germination the behavior was quadratic decreasing in all environments (Figure 2A).

In the DCR environment, where the best germination result was obtained, the highest percentage was obtained until 90 days ( $88 \%$ ), reducing to $45 \%$ and $43 \%$ at 180 and 270 days, respectively, with an increase at 360 days (57\%) (Figure 2A).

In the WCC environment, there was no germination after 90 days of storage. This result may be associated with the gain in moisture by the diaspores in this environment (Table 2), which after undergoing constant low temperature, may have suffered freezing, expansion, and rupture of the cell membrane (Marcos Filho, 2005). This situation was not evident in the REF, as this environment was drier and caused the loss of diaspore humidity, with a lower temperature effect (Table 2). In the SCA, there was a reduction in germination at 90 days, being null at 270 and 360 days (Figure 2A). In this environment there were great variations in the maximum $\left(26^{\circ} \mathrm{C}\right)$ and minimum $\left(16.4{ }^{\circ} \mathrm{C}\right)$ temperatures and high relative humidity (average 79\%), compromising the quality of diaspores.
Loss of viability in seeds, when stored in the WCC chamber was also observed in studies with Tabebuia caraiba (Mart.) Bureau (Guedes et al., 2012) and Handroanthus heptaphyllus (Tonetto et al., 2015).

According to Carvalho \& Nakagawa (2000), changes in temperature and relative humidity of air cause changes in the water content of seeds stored in permeable packaging. These results demonstrate that low temperature and relative humidity are of extreme importance for the conservation of the vigor of cabreúva diaspores. Gasparin et al. (2013) also reported that the storage of seeds of Parapiptadenia rigida (Benth.) Brenan in a room without temperature and relative humidity control was unfavorable for the maintenance of viability during a one-year storage period.

For seedlings length, the highest averages were observed in the DCR room environment at 90, 180, 270, and 360 days after storage (Figure 2C). Seedling dry matter in the DCR room environment was lower at 90 days and higher with the other treatments (Figure 2D). In a storage study of Tabebuia roseoalba (Ridl.) seeds with sand, after 24 months in a refrigerated chamber ( 14 to $20{ }^{\circ} \mathrm{C} ; 74 \%$ to $82 \% \mathrm{RH}$ ), germination percentage, seedling length, and dry matter weight were reduced (Abbade \& Takaki, 2014).

Regarding dead diaspores, the lowest averages were observed in the DCR environment room in all evaluations (Figure 3A). According to Brasil (2013) dead diaspores are those that do not show any sign of the beginning of germination, and generally, they are softened and with pathogens that are sometimes not apparent.

For electrical conductivity (EC) there was an interaction $(p<0.05)$ between environments and time of storage. Based on initial EC $\left(11.27 \mu \mathrm{S} \mathrm{m}^{-1} \mathrm{~g}^{-1}\right)$, storage in any condition increased leachate loss, favoring the exudation of substances. It was observed that only the SSF room had the lowest values from 90 to 180 days $\left(25.0 \mu \mathrm{S} \mathrm{cm}^{-1} \mathrm{~g}^{-1}\right)$, in relation to the environments in the other rooms and the REF condition, and was significantly higher from 90 to 360 days in the WCC chamber $\left(50.7\right.$ and $50.9 \mu \mathrm{S} \mathrm{cm}^{-1} \mathrm{~g}^{-1}$, respectively) (Figure 3B).

Table 2. Moisture content (\%) of Myrocarpus frondosus Allemão diaspores under different storage conditions at 0, 90, 180, 270, and 360 days, Santa Maria, RS.

\begin{tabular}{cccccc} 
Environment & \multicolumn{5}{c}{ Storage (days) } \\
\cline { 2 - 6 } & $\mathbf{0}$ & $\mathbf{9 0}$ & $\mathbf{1 8 0}$ & $\mathbf{2 7 0}$ & $\mathbf{3 6 0}$ \\
RAC & $9.25 \pm 0.29$ & $13.52 \pm 0.04$ & $13.48 \pm 0.16$ & $13.55 \pm 0.25$ & $11.66 \pm 0.11$ \\
DCR & $9.25 \pm 0.29$ & $7.05 \pm 0.05$ & $6.98 \pm 0.05$ & $6.88 \pm 0.07$ & $6.73 \pm 0.09$ \\
WCC & $9.25 \pm 0.29$ & $16.99 \pm 0.24$ & $15.97 \pm 0.03$ & $14.18 \pm 0.07$ & $13.88 \pm 0.02$ \\
REF & $9.25 \pm 0.29$ & $7.98 \pm 0.31$ & $7.44 \pm 0.01$ & $8.61 \pm 0.21$ & $6.11 \pm 0.04$
\end{tabular}

Being: RAC - room in ambient condition; DCR - dry and cold room; WCC - wet and cold chamber; REF - refrigerator. 

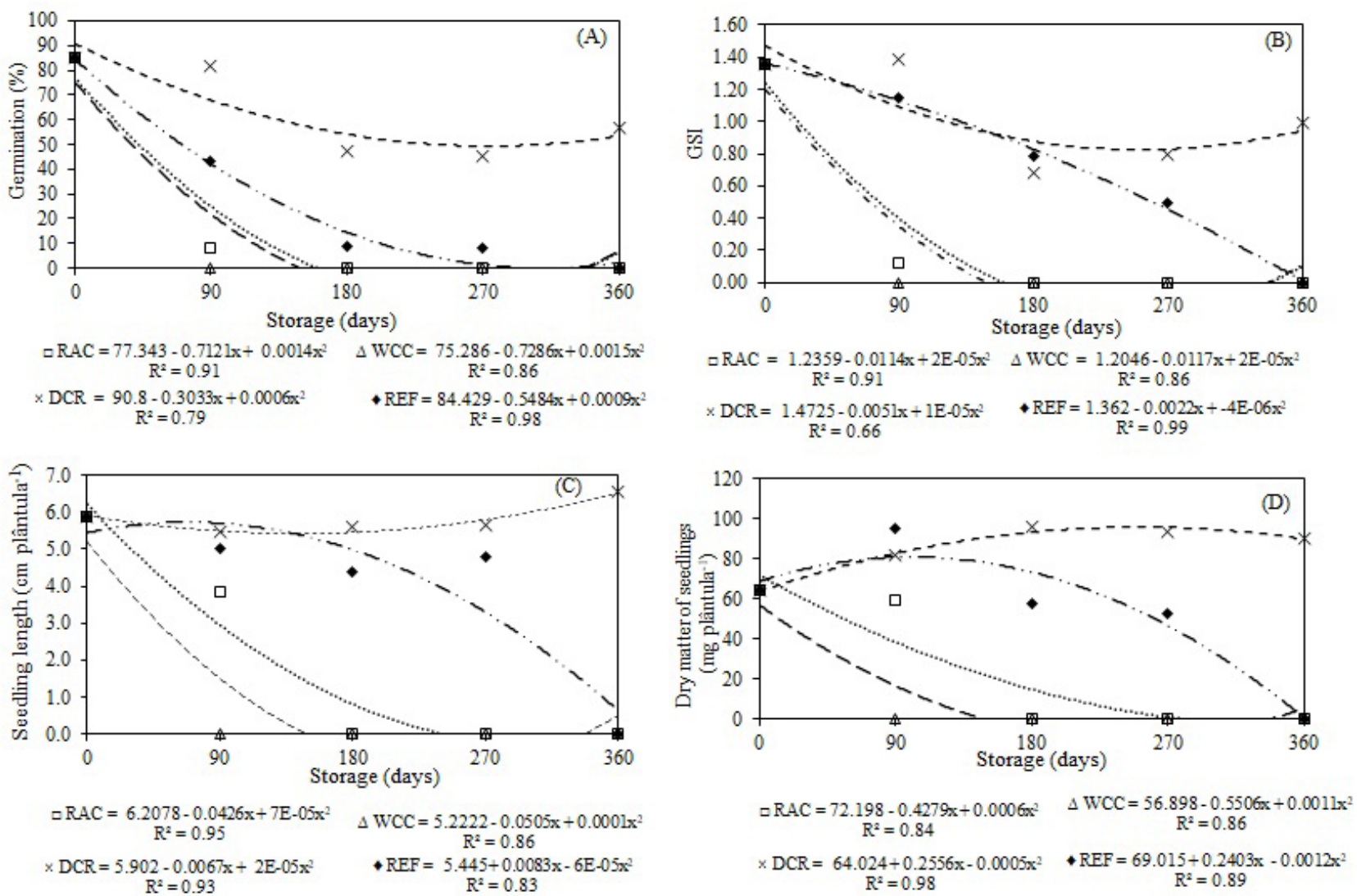

Figure 2. Percentage of germination (A); germination speed index (GSI) (B); length of seedlings (C); and dry matter of seedlings (D) of Myrocarpus frondosus Allemão under different environments and storage times. RAC - room at ambient condition; DCR - dry and cold room; WCC - wet and cold chamber; REF - refrigerator.

The increase in the degree of humidity was undesirable for the conservation of diaspores (Table 2), a fact that was possibly associated with loss of cell membrane integrity, indicated by the highest values of EC, mainly in the storage environments of RAC and WCC. The loss in viability of diaspores is correlated with the rupture of membranes causing the release of cellular solutes important for the functioning of the cell (Marcos Filho, 2005). According to Karrfalt (2008), the deteriorated or dead seeds release greater amounts of electrolytes than those that are intact and with greater vigor, consequently, increasing the conductivity of the solution.

The seeds can be classified into three groups regarding the behavior in relation to desiccation tolerance and storage at low temperatures: orthodox, intermediate, and recalcitrant (Roberts, 1973; Ellis et al., 1990). Seeds classified as intermediates are those that tolerate the reduction in humidity of contents up to $7 \%$ to $13 \%$ (Ellis et al., 1990), or those that are intolerant to freezing temperatures for storage such as $-20^{\circ} \mathrm{C}$. Myrocarpus frondosus is described as recalcitrant (Lorenzi, 2002) to storage based on the FEPAGRO database (Wielewicki et al., 2006). It was observed that during storage, the diaspores maintained their viability for one year in the DCR room; therefore, according to these results the diaspores of this species cannot be classified as recalcitrant.

For sanitary, there was interaction $(p<0.05)$ between treatments (environment $\times$ storage). In general, the diaspores showed better sanitary conditions in the RAC room and worse in the DCR rooms (Table 3). Alternaria spp. presented a lower incidence at 90 days in the RAC room and in WCC chamber (1\%), differing from the others (RAC room and REF). For Aspergillus spp., occurrence was observed at 90 days only in the RAC room and DCR room (37\% and $13 \%$, respectively. For Penicillium spp. the highest incidence at 90 days was in the RAC room (16\%), differing from the others, and occurred at 180, 270, and 360 days (Table 3).

The presence of Aspergillus spp. and Penicillium spp. in seeds is common, indicating that storage problems may have occurred, and should be better studied. Aspergillus spp. increased significantly in the DCR room environment, mainly at 180 days, although presenting the best germination results, GSI, seedling length, and seedling dry matter and lower averages of dead diaspores and EC, thus indicating the possibility of seed treatment before storage. 
Aspergillus spp. and Penicillium spp. occur mainly under storage conditions, but superficially, it is possible to perform the disinfection of the diaspores (Bewley \& Black, 2012). These genera have the ability to reduce the germination potential of seeds and cause the embryo to die (Cherobini et al., 2008). In addition, the same authors described that the increased presence of the fungus Aspergillus spp. during storage was indicative of deterioration of Cedrela fissilis Vell. and was also responsible for its rotting, consequently increasing the occurrence of Penicillium spp. The percentage of dead diaspores was higher in the environment of the WCC chamber (Figure $3 \mathrm{~A}$ ) and fungi associated with diaspores may have caused deterioration.

Colletotrichum spp. occurrence was only observed at 90 days in the REF condition (Table 3). However, this genus has pathogenic potential and is associated with seeds of many species and may be responsible for the great variation in seed germination (Carvalho \& Muchovej, 1991). The greater incidence of Cladosporium spp. at 90 days in the DCR room ( $83 \%$ ) did not differ from that in the other environments. At 180 days, the greatest occurrence was in the DCR room and REF ( $94 \%$ and $93 \%$, respectively), and differed from that of the other environments and at 270 days, its occurrence decreased in all environments.

Fusarium spp. presented a higher incidence in the DCR room and REF differing from that in the other environments (Table 3 ). However, its presence did not interfere with the germination of seeds in the DCR room environment, considering their occurrence since the initial phase and high percentage of germination and GSI, when compared to that in other storage conditions.

In contrast, one must be aware of its occurrence in the seedlings in the nursery, mainly when produced on inert substrates, as they possibly did not find antagonistic control fungi, as normally occurs in the soil. Fusarium spp. was reported causing pre- and post-emergence tipping over of
Parapiptadenia rigida (Maciel et al., 2012) and Cedrela fissilis (Lazarotto et al., 2012) seedlings. It was noted that the fungus is transmitted via seeds to seedlings, causing lesions in the roots, evolving to the lap and causing tipping.

Mucor and Rhizopus were detected with low incidence in the diaspores of cabreúva (Table 3). However, as Rhizopus spp. are considered fungi with low potential to damage seeds, disinfection should be used only in conditions of high incidence. In view of the significant occurrence of fungi in cabreúva diaspores, as well as in other native species (Maciel et al., 2012; Tonetto et al., 2015; Aimi et al., 2016), the importance of detecting these fungi is evident in order to avoid future problems in the nursery. According to Benetti et al. (2009), the inferior quality of seedlings of native forest species may be related to phytosanitary problems in their seeds, and thus, the need for detection for later control of these pathogens.

Germination reduction after 180 days in the DCR room may have been triggered by the action of pathogens, as the EC did not change at 90 and 180 days, with germination of $88 \%$ and $45 \%$, respectively (Figure 3B). Thus, the action of fungi may have caused the cell membrane to break down, with an increase in EC at 270 days $\left(40.43 \mu \mathrm{S} \mathrm{cm}^{-1} \mathrm{~g}^{-1}\right)$, a condition that still allowed germination, but which indicates a reduction expressed at 360 days. In addition, studies investigating the pre-storage treatment of diaspores are important to maximize the potential for species use in nurseries throughout the year and increasing the period suitable for sowing in nurseries.

Seed drying at about $7 \%$ associated with low temperature and $\mathrm{RH}$ of the environment can reduce and/or inhibit the development of pathogens in the initial phase; consequently, conserving diaspores with greater viability for longer periods. Similar studies are suggested that include moisture reduction and the treatment of diaspores before storage, in addition to the use of different packaging material.
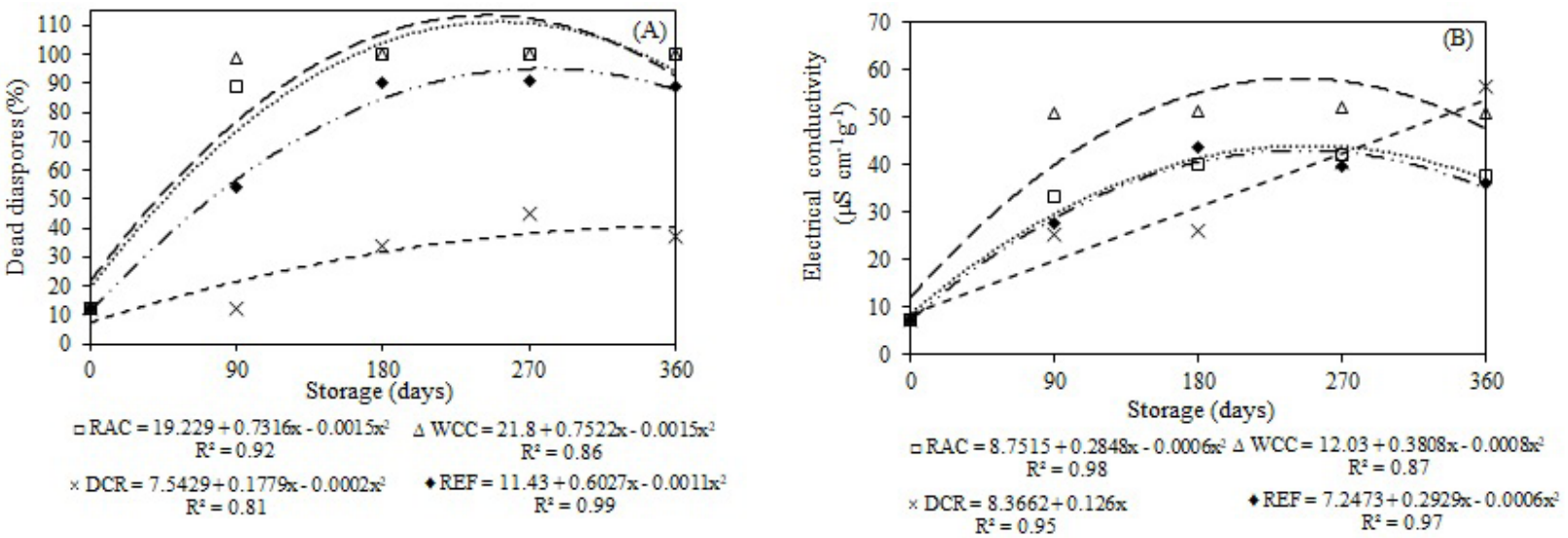

Figure 3. Dead diaspores (A) and electrical conductivity (B) under different environments at $0,90,180,270$, and 360 days after storage, Santa Maria, RS. RAC - room at ambient condition; DCR - dry and cold room; WCC - wet and cold chamber; REF - refrigerator. 
Table 3. Fungal genera associated with Myrocarpus frondosus Allemão diaspores at 90, 180, 270, and 360 days after storage under different environments, Santa Maria, RS.

\begin{tabular}{|c|c|c|c|c|c|c|c|c|}
\hline \multirow{3}{*}{ Treatment } & \multicolumn{5}{|c|}{ Alternaria spp. (\%) } & \multicolumn{3}{|c|}{ Aspergillus spp. (\%) } \\
\hline & \multicolumn{8}{|c|}{ Storage (days) } \\
\hline & 90 & 180 & 270 & 360 & 90 & 180 & 270 & 360 \\
\hline RAC & $1 \mathrm{Aa}^{*}$ & $0 \mathrm{Aa}$ & $0 \mathrm{Aa}$ & $0 \mathrm{Aa}$ & $37 \mathrm{Bb}$ & $25 \mathrm{Ba}$ & $10 \mathrm{Aa}$ & $8 \mathrm{Aa}$ \\
\hline DCR & $20 \mathrm{Cb}$ & $0 \mathrm{Aa}$ & $0 \mathrm{Aa}$ & $10 \mathrm{Bb}$ & $13 \mathrm{Ab}$ & $43 \mathrm{Bb}$ & $23 \mathrm{Ab}$ & $11 \mathrm{Aa}$ \\
\hline WCC & $1 \mathrm{Aa}$ & $0 \mathrm{Aa}$ & $0 \mathrm{Aa}$ & $0 \mathrm{Aa}$ & $0 \mathrm{Aa}$ & $6 \mathrm{Aa}$ & $4 \mathrm{Aa}$ & $11 \mathrm{Aa}$ \\
\hline REF & $19 \mathrm{Bb}$ & $0 \mathrm{Aa}$ & $4 \mathrm{Ab}$ & $6 \mathrm{Ab}$ & $0 \mathrm{Aa}$ & $67 \mathrm{Cb}$ & $54 \mathrm{Cc}$ & $10 \mathrm{Ba}$ \\
\hline Mean & & & 3.81 & & & & 57.52 & \\
\hline CV (\%) & & & 6.58 & & & & 14.69 & \\
\hline \multirow{3}{*}{ Treatment } & \multicolumn{5}{|c|}{ Colletotrichum spp. (\%) } & \multicolumn{3}{|c|}{ Cladosporium spp. (\%) } \\
\hline & \multicolumn{8}{|c|}{ Storage (days) } \\
\hline & 90 & 180 & 270 & 360 & 90 & 180 & 270 & 360 \\
\hline RAC & $0 \mathrm{Aa}$ & $0 \mathrm{Aa}$ & $0 \mathrm{Aa}$ & $0 \mathrm{Aa}$ & $32 \mathrm{Ba}$ & $42 \mathrm{Ba}$ & $1 \mathrm{Aa}$ & $0 \mathrm{Aa}$ \\
\hline DCR & $0 \mathrm{Aa}$ & $0 \mathrm{Aa}$ & $0 \mathrm{Aa}$ & $0 \mathrm{Aa}$ & $83 \mathrm{Cb}$ & $94 \mathrm{Cb}$ & $0 \mathrm{Aa}$ & $12 \mathrm{Bb}$ \\
\hline WCC & $0 \mathrm{Aa}$ & $0 \mathrm{Aa}$ & $0 \mathrm{Aa}$ & $0 \mathrm{Aa}$ & $35 \mathrm{Ba}$ & $25 \mathrm{Ba}$ & $7 \mathrm{Aa}$ & $0 \mathrm{Aa}$ \\
\hline REF & $18 \mathrm{Bb}$ & $0 \mathrm{Aa}$ & $0 \mathrm{Aa}$ & 0 Aa & $45 \mathrm{Ba}$ & $93 \mathrm{Cb}$ & $5 \mathrm{Aa}$ & $53 \mathrm{Bc}$ \\
\hline Mean & & & 1.12 & & & & 39.92 & \\
\hline $\mathrm{CV}(\%)$ & & & 4.56 & & & & 17.38 & \\
\hline \multirow{3}{*}{ Treatment } & \multicolumn{5}{|c|}{ Fusarium spp. (\%) } & \multicolumn{3}{|c|}{ Penicillium spp. (\%) } \\
\hline & \multicolumn{8}{|c|}{ Storage (days) } \\
\hline & 90 & 180 & 270 & 360 & 90 & 180 & 270 & 360 \\
\hline RAC & $57 \mathrm{Ba}$ & $2 \mathrm{Aa}$ & $4 \mathrm{Aa}$ & $2 \mathrm{Aa}$ & $16 \mathrm{Bb}$ & $1 \mathrm{Aa}$ & $4 \mathrm{Aa}$ & $90 \mathrm{Cc}$ \\
\hline DCR & $99 \mathrm{Ab}$ & $63 \mathrm{Bb}$ & $100 \mathrm{Bb}$ & $95 \mathrm{Bb}$ & $5 \mathrm{Aa}$ & $4 \mathrm{Aa}$ & $1 \mathrm{Aa}$ & $5 \mathrm{Aa}$ \\
\hline WCC & $39 \mathrm{Ba}$ & $3 \mathrm{Aa}$ & $0 \mathrm{Aa}$ & $4 \mathrm{Aa}$ & $3 \mathrm{Aa}$ & $0 \mathrm{Aa}$ & $60 \mathrm{Bb}$ & $90 \mathrm{Cc}$ \\
\hline REF & $96 \mathrm{Bb}$ & $59 \mathrm{Ab}$ & $97 \mathrm{Bb}$ & $84 \mathrm{Bb}$ & $2 \mathrm{Aa}$ & $19 \mathrm{Bb}$ & $4 \mathrm{Aa}$ & $20 \mathrm{Bb}$ \\
\hline Mean & & & 50.25 & & & & 20.50 & \\
\hline CV (\%) & & & 29.23 & & & & 14.66 & \\
\hline \multirow{3}{*}{ Treatment } & \multicolumn{5}{|c|}{ Mucor spp. (\%) } & \multicolumn{3}{|c|}{ Rhizopus spp. (\%) } \\
\hline & 90 & 180 & 270 & 360 & 90 & 180 & 270 & 360 \\
\hline & \multicolumn{8}{|c|}{ Storage (days) } \\
\hline RAC & $0 \mathrm{Aa}$ & $0 \mathrm{Aa}$ & $97 \mathrm{Bd}$ & $0 \mathrm{Aa}$ & $7 \mathrm{Ab}$ & $0 \mathrm{Aa}$ & $5 \mathrm{Aa}$ & $0 \mathrm{Aa}$ \\
\hline DCR & $0 \mathrm{Aa}$ & $0 \mathrm{Aa}$ & $0 \mathrm{Aa}$ & $0 \mathrm{Aa}$ & $4 \mathrm{Aa}$ & $32 \mathrm{Bb}$ & $17 \mathrm{Ab}$ & $12 \mathrm{Ab}$ \\
\hline WCC & $0 \mathrm{Aa}$ & $0 \mathrm{Aa}$ & $4 \mathrm{Bb}$ & $0 \mathrm{Aa}$ & $1 \mathrm{Aa}$ & $0 \mathrm{Aa}$ & $0 \mathrm{Aa}$ & $0 \mathrm{Aa}$ \\
\hline REF & $0 \mathrm{Aa}$ & $0 \mathrm{Aa}$ & $8 \mathrm{Bc}$ & $0 \mathrm{Aa}$ & $0 \mathrm{Aa}$ & $2 \mathrm{Aa}$ & $2 \mathrm{Aa}$ & $4 \mathrm{Aa}$ \\
\hline Mean & & & 6.81 & & & & 5.37 & \\
\hline CV (\%) & & & 5.14 & & & & 11.90 & \\
\hline
\end{tabular}

\section{CONCLUSIONS}

The substrates between sand and between vermiculite are recommended for the germination of diaspores of Myrocarpus frondosus Allemão.

The species does not show recalcitrant behavior in relation to storage and can be stored in a cold and dry environment for 360 days.
Fungal incidence increased the deterioration of the diaspores after 180 days of storage in a cold and dry environment.

\section{ACKNOWLEDGEMENTS}

The authors would like to thank Coordenação de Aperfeiçoamento de Pessoal de Nível Superior (CAPES) for granting scholarship to the first author and to the Conselho Nacional de Desenvolvimento Científico e Tecnológico (CNPq) 
for the scholarship of productivity in research provided to the second author.

\section{SUBMISSION STATUS}

Received: 2 June 2018

Accepted: 19 June 2020

Associate editor: Juliana Müller Freire (i)

\section{CORRESPONDENCE TO Suelen Carpenedo Aimi}

Universidade Federal de Santa Maria (UFSM), Centro de Ciencias Rurais, Departamento de Ciências Florestais, Av. Roraima, $n^{\circ} 1000$, 97105-900, Santa Maria, RS, Brasil

E-mail: suaimi@gmail.com

\section{REFERENCES}

Abbade L, Takaki M. Tetrazolium test for quality assessment of seeds of Tabebuia roseoalba (Ridl.) Sandwith Bignoniaceae, subjected to storage. Revista Árvore, 2014; 38(2): 233-240.

Aimi SC, Araujo MM, Muniz MFB, Walker C. Teste de sanidade e germinação em sementes de Cabralea canjerana (Vell.) Mart. Ciência Florestal, 2016; 26(4): 1361-1370.

Araujo MDN, Ferraz M, Américo FKA, Silva FFS, Dantas BF, Cruz CRP. Seed quality of Amburana cearensis (Allemão) A.C. $\mathrm{Sm}$. (Fabaceae) is influenced by storage condition. Journal of Seed Science, 2017; 39(4): 401-409.

Barnett HL, Hunter BB. Ilustred genera of imperfect fungi. 3 Ed. Minnesota: Burgess Publishing Company: 1999.

Benetti SC, dos Santos ÁF, de Souza MAC, de Souza JFD. Levantamento de fungos em sementes de cedro e avaliação da patogenicidade de Fusarium sp. e Pestalotia sp. Pesquisa Florestal Brasileira, 2009; 58:81-85.

Bewley JD, Black M. Physiology and biochemistry of seeds in relation to germination: Viability, dormancy, and environmental control. v.2. Springer Science \& Business Media, 2012.

Brasil. Regra para análise de sementes. Ministério da Agricultura, Pecuária e Abastecimento. Secretaria de Defesa Agropecuária, Brasília: MAPA/ACS, 2009a.

Brasil. Manual de análise sanitária de sementes. Ministério da Agricultura, Pecuária e Abastecimento. Secretaria de Defesa Agropecuária, Brasília: MAPA/ACS, 2009b.

Brasil. Instruções para análise de espécies florestais. Ministério da Agricultura, Pecuária e Abastecimento. Secretaria de Defesa Agropecuária, Brasília: MAPA/ACS, 2013.

Carvalho NM, Nakagawa J. Sementes: ciência, tecnologia e produção. 4ed. Jaboticabal: FUNEP, 2000.

Carvalho PER. Espécies Arbóreas Brasileiras. Brasília: EMBRAPA Informação Tecnológica. Colombo, PR: EMBRAPA Florestas, 2003.

Carvalho WL de, Muchovej JJ. Fungos associados a sementes de essências florestais. Revista Árvore, 1991: 15(2): 173-178, 1991.
Cherobini EAI, Muniz MFB, Blume E. Avaliação da qualidade de sementes e mudas de cedro. Ciência Florestal, 2008; 18(1):65-73.

Ellis RH, Hong TD, Roberts EH. An intermediate category of seed storage behaviour? I. Coffee. Journal Experimental Botany, 1990; 41(230):1167-1174.

EQUIPE ESTATCAMP. Software Action. Estatcamp- Consultoria em estatística e qualidade, São Carlos - SP, Brasil. 2014.

Ferreira DF. Sisvar: a Guide for its Bootstrap procedures in multiple comparisons. Ciência e Agrotecnologia, 2014; 38(2): 109-112.

Gasparin E, Araujo MM, Tolfo CV, Foltz DRB, Magistrali PR. Substrates for germination and physiological quality of storage seeds of Parapiptadenia rigida (Benth.) Brenan. Journal of Seed Science, 2013; 35(1): 77-85.

Guedes RS, Alves EU, Melo PAFRD, Moura SDSS, Silva RDSD. Storage of Tabebuia caraiba (Mart.) Bureau seeds in different packaging and temperatures. Revista Brasileira de Sementes, 2012; 34(3): 433-440.

Huller A, Coelho GC, Meneghello GE, Peske ST. Avaliação da semeadura direta de duas espécies de árvores neotropicais com o uso de insumos naturais. Revista Árvore, 2017; 41(4): 1-8.

Karrfalt RP. Seed Testing. In: Bonner FT, Karrfalt RP. (Ed.). The woody plant seed manual. Agriculture Handbook 727. Washington, DC, U.S.: Department of Agriculture, Forest Service, 2008.

Kissmann C, Scalon SDPQ, Mussury RM, Robaina AD. Germinação e armazenamento de sementes de Albizia hasslerii (Chod.) Burkart. Revista Brasileira de Sementes, 2009; 31(2): 104-115.

Lazarotto M, Muniz MFB, Beltrame R, dos Santos ÁF, Maciel CG, Longhi SJ. Sanidade, transmissão via semente e patogenicidade de fungos em sementes de Cedrela fissilis procedentes da região sul do Brasil. Ciência Florestal, 2012; 22(3): 493-503.

Lorenzi H. Árvores Brasileiras. Manual de Identificação e Cultivo de Plantas Arbóreas Nativas do Brasil. Nova Odessa, São Paulo: Plantarum, 2002.

Maciel CG, Muniz MFB, Santos AF dos, Lazarotto M. Deteç̧ão, transmissão e patogenicidade de fungos em sementes de angicovermelho (Parapiptadenia rigida). Summa Phytopathologica, 2012; 38(4): 323-328.

Maguire JD. Speeds of germination-aid selection and evaluation for seedling emergence and vigor. Crop Science, 1962; 2: 176-177.

Marcos Filho J. Fisiologia de sementes de plantas cultivadas. Piracicaba: Fealq, 2005.

Nguyen TP, Cueff G, Hegedus DD, Rajjou L, Bentsink L. A role for seed storage proteins in Arabidopsis seed longevity. Journal of Experimental Botany, 2015; 66(20): 6399-6413.

Ribeiro-Oliveira JP, Ranal MA. Sementes florestais brasileiras: início precário, presente inebriante e o futuro, promissor? Ciência Florestal, 2014; 24(3): 771-784.

Roberts EH. Predicting the storage life of seeds. Seed Science and Technology, 1973; 1: 499-514.

Rocha CRM, Costa DS, Novembre ADL, Cruz ED. Morfobiometria e germinação de sementes de Parkia multijuga Benth. Nativa, 2014; 2(1): 42-47. 
Santi II, Gatto DA, Machado MRG, dos Santos PSB, Freitag RA. Chemical Composition, Antioxidant and Antimi- crobial Activity of the Oil and Plant Extract Myrocarpus frondosus Allemão. American Journal of Plant Sciences, 2017; 8: 1560-1571.

Schmidt L. Tropical forest seed. New York: Springer, 2007.

Souza EB, Pacheco VM, Matos VP, Ferreira RLC. Germinação de sementes de Adenanthera pavonina L. em função de diferentes temperaturas e substratos. Revista Árvore, 2007; 31(3): 437-443.

Tonetto T da S, Araujo MM, Muniz MFB, Walker C, Berghetti ÁLP. Storage and germination of seeds of Handroanthus heptaphyllus (Mart.) Mattos. Journal of Seed Science, 2015; 37(1): 040-046.
Vicente D, Oliveira LMD, Tonetti OAO, Silva AA, Liesch PP, Engel ML. Viabilidade de Sementes de Ocotea puberula (Rich.) Ness ao Longo do Armazenamento. Floresta e Ambiente, 2016; 23(3): 418-426.

Walters C. Orthodoxy, recalcitrance and in-between: describing variation in seed storage characteristics using threshold responses to water loss. Planta, 2015; 242: 397-406.

Wielewicki AP, Leonhardt C, Schlindwein G, Medeiros AC de S. Proposta de padrões de germinação e teor de água para sementes de algumas espécies florestais presentes na região Sul do Brasil. Revista Brasileira de Sementes, 2006; 28(3): 191-197. 